\title{
Hemoglobin and Ferritin Concentration in Cord Blood
}

\section{El- Kasem A El- Gamil 1, Dr. Remon M Youssef ${ }^{2}$, Dr. Mohamed Mansour ${ }^{3}$ \\ Dr. Noha Ewaise Soliman 4}

1- Professor of pediatrics, Faculty of Medicine, Fayoum University .

2- Lecturer of pediatrics ,Faculty of Medicine, Fayoum University.

3- Lecturer of clinical pathology, Faculty of Medicine, Fayoum University.

4- M .B. B.CH, Fayoum University, Egypt.

\begin{abstract}
Background: Neonatal anemia occurs when there is a decrease in the baby's red blood cell count before delivery. Fetal anemia is relatively rare but serious condition an Immune- Related cause is the most common involving red blood cell (RBC) alloimmunization followed by non-immune causes such as parvovirus B19 infection and other congenital infection. Other causes include genetic or metabolic syndromes and vascular tumors of the baby or placenta.
\end{abstract}

Patients and methods: This cross- sectional study is conducted on 200 Neonates, delivered by normal or cesarean section in Fayoum University Hospital\& Fayoum General Hospital. Hemoglobin and Ferritin levels in cord blood are determined.

Results: The mean \pm SD of HB \& Ferritin was: 12.61 $\pm 2.44 \%$ and $104.96 \pm 98.17$ respectively. About one eighth 24 / 200 (12.0\%) of studied neonates had ferritin deficiency (FD).

Conclusion: In Our study, more than one third (39\%) of study neonates had anemia. One eights 24/ 200
(12\%) of neonates had Ferritin deficiency. 9.5\% of study neonates had iron deficiency anemia (IDA). Prevalence of Iron deficiency anemia in males was higher than in females (12\% Vs $7.7 \%$ ) with no statistical significance $p=0.301$. Finally we conclude that iron deficiency is important cause of anemia.

Key words: Neonatal anemia, Hemoglobin, Ferritin, cord Blood .

\section{Hemoglobin and Ferritin Concentration in Cord Blood}

\section{Introduction :}

Anemia is defined as a reduction of the red blood cell volume or hemoglobin concentration below the range of values occurring in healthy persons to meet the tissue demands for oxygen delivery

(Glader, 2007).

\section{Erythropoiesis:}

Newborns have about 4.7 million red blood cells per cubic millimeter of blood and women have 
about 4.7 million per cubic millimeter of blood

(Karine, 2007).

The actual process of making red blood cells is called erythropoiesis. In Greek, erythropoiesis means "red," and poesies means "the making of things." So Erythropoiesis is the process of manufacturing, recycling, and regulating the number of red blood cells (Van Meter, 2008).

\section{$\gg$ Exclusion Criteria:}

- Any new born with major congenital anomalies or with major surgical conditions were excluded.

\section{$\nabla$ All cases are subjected to:}

1- Full history taking with focusing on history for maternal illness, maternal drugs, risk factors for Anemia e.g. RH or nutritional deficiencies iron, folate, vitamin B12.

2- Examination of the new born immediately after birth: general and systemic

$$
\text { examination. }
$$

3- Laboratory investigation:

Hemoglobin and ferritin levels in cord blood are determined. Two milli liters of blood is collected from the cord of each new born into EDTA bottle for hemoglobin analysis and another $2 \mathrm{mls}$ into a plain bottle for serum erythrocytes. The regulation of EPO gene expression involves an oxygen sensing mechanismferritin assay. and both hypoxia and anemia stimulate erythropoiesis by stimulating mRNA transcription and EPO production (Glader, 2007).

\section{Patients and Methods :}

This prospective cross- sectional study is conducted on 200 Neonates, delivered by normal or cesarean section in Fayoum University Hospital \& Fayoum General Hospital from April 2018 to July 2018.

\section{PInclusion Criteria:}

- All neonates born either by vaginal delivery or by cesarean section.

- All neonate of both genders.

- Gestational age $\geq 37$ weeks.

\section{Statistical Methods:}

Data was statistically analyzed using standard computer program (SPSS) software package. Quantitative was presented as mean +/- SD or medium (range) when approiate. Quantitative data was presented as number $\&$ percentages. Different methods of differences and association were used.

\section{Ethical Consideration:}

This study was reviewed by the faculty of Medicine Research Ethical Committee. We informed the parent of the new born about the objectives of the study, the examination, investigations that have been done. Also, the confidentiality of their information and their rights not to participate in the study. 


\section{Results:}

In Table (2) reveals that mean $\pm \mathrm{SD}$ of $\mathrm{HB}$ and Ferritin were:

The study was conducted on 200 newborns delivered either $161 \pm 2.44$ and $104.96 \pm 98.17$, respectively.

cesarean section or by normal vaginal delivery at Fayoum

\section{General Hospital \& Fayoum University Hospital. We}

exclude babies with major congenital anomalies and babies with major surgical conditions.

Most of studied neonates were female 117/ 200 (58.5\%) while male constituted $41.5 \%$ of them.

In Table (3) and Figure (2) Ferritin deficiency is diagnosed by serum Ferritin level below $25 \mathrm{ng} / \mathrm{ml}$ (MelindRatini, Do, Ms 2017).

About one eighth of studied neonates 24/200 $(12.0 \%)$ had Ferritin deficiency.

\section{Discussion:}

Neonatal Anemia was diagnosed by hemoglobin level less than $13 \mathrm{gm} / \mathrm{dl}$ (Kirsten. Crowley, 2005). Iron deficiency anemia was diagnosed by hemoglobin level less than $13 \mathrm{gm} / \mathrm{dl}$ weeks of life as treatment of umbilical vessels at the time of (Kirsten. Crowley, 2005) and serum ferritin level below 25 livery, gestational age of the infant and others should be ng/ ml (MelindRatini, 2017). Ferritin definciency was diagnosed by serum ferritin level below $25 \mathrm{ng} / \mathrm{ml}$

(MelindRatini, 2017).

considered in mind. (Kaushansky et al., 2010)

Most of studied neonates were female 117/ 200 (58.5\%) while male constituted $41.5 \%$ of them.

According to this criteria, out of study neonates about more than one third (78/200) $(39 \%)$ of study neonates had anemia. The mean \pm SD of HB and ferritin were: $12.61 \pm 2.44 \&$ $104.96 \pm 98.7$, respectively. Mean \pm SD of mother HB was About one eighth(24/200) (12\%) of study neonates had ferritin lower in neonates with IDA than in those without $(10.31 \pm$ deficiency. About (19/200) (9.5\%) had iron deficiency anemia

1.18 vs $11.24 \pm 1.60$ ), with statistical significance $p=0.014$. (IDA).

This is similar to a study done by (Adewumi Adediran et

Prevalence of Iron deficiency anemia (IDA) in males was higher than in females (12\% vs $7.7 \%$ ) with no statistical al., 2013) and (Al- Hilli, 2010). significance $\mathrm{p}=0.301$.prevalence of FD in males was highdiean \pm SD of mother HB was lower in neonates with FD than in females ( $14.5 \%$ vs $10.3 \%$ ), with no statistical significance $\mathrm{p}=0.368$. than in those without $(10.36 \pm 1.26$ vs $11.26 \pm 1.60)$ with a statistical significance $\mathrm{p}=0.009$. There was a positive The mean \pm SD of HB and ferritin were: $12.61 \pm 2.44 \&$ $104.96 \pm 98.7$, respectively. Mean $\pm \mathrm{SD}$ of mother $\mathrm{HB}$ was mother, $\mathrm{r}=0.248$ and $\mathrm{p}=0.006$.

lower in neonates with IDA than in those without (10.31 \pm There was a positive correlation between HB of mothers vs $11.24 \pm 1.60$ ), with statistical significance $p=0.014$. Imd ferritin of neonates with no statical significance.

Table (1) and figure (1) show that in our study group neonates, female were 117/200 (58.5\%) while male constituted $41.5 \%$ of them. 
This is similar to a study done by (Singala et al., 2008, Rumi Debbarma et al.,2015, Swetha et al., 2017, Agrawal \& Srivastava P, 2017).

Prevalence of IDA in neonates from anemic mothers was higher than those from non-anemic mothers (15.2\% Vs 4.6\%) with statistical significance $\mathrm{p}=0.011$.

This is similar to a studt done by (Adewumi Adediran et al., 2013) and (Al- Hilli, 2010).

Similar to our results, A study was conducted in neonatal care unit of the tertiary hospital by (Swetha et al., 2017). This prospective study was conducted in a tertiary care institution of Andhra Pradesh from November 2014 to August 2016. Total 195 mothers and new born pairs are enrolled in the study. Male constituted $54.7 \%$ (94) and females constituted $45.3 \%$ (78) of the cases. In our study, male constituted $41.5 \%$ (83) while female constituted $58.5 \%$ (117). Significant positive correlation was found between maternal HB and neonatal Ferritin (Pearson's correlation coefficient $=0.26, \mathrm{P}=0.002$ ) . The mean $\mathrm{HB}$ and ferritin values were $(14.5 \pm 2.1 \mathrm{~g} / \mathrm{dl}) \&(128.9 \pm 80.7$ $\mu \mathrm{g} / \mathrm{dl})$.

\section{Conclusion:}

The percentage of neonatal anemia was $39 \%$, out of them $12 \%$ had FD.

Percentage of studied neonates having IDA was $9.5 \%$. Iron deficiency anemia is important cause of anemia which affects roughly one-quarter of the world' population. It is now documented that even mild iron deficiency in the mother reduced iron stores in the fetus, resulting in neonatal-Iron deficient condition.

\section{Recommendations:}

1- Optimization of maternal hemoglobin with good nutrition and iron supplementation.

2-This study shows direct correlation between maternal and fetal hemoglobin levels. We, therefore stress the importance of preventing maternal anemia and maintaining adequate Iron storage in mothers during pregnancy to ensure better maternal and fetal outcome.

\section{References}

Adediran A, Gbadegesin A, Adeyemo TA, Akinbami AA, Akanmu AS, Osunkalu V, et al. Haemolobin and ferritin concenrations of pregnant women at term. Obstet Med. 2011;4:152-5.

DAl-Hilli M.The effect of maternal anaemia on cord blood haemoglobin and newborn birth weight. Karbala J Med. 2010;2:8-9.

>Glader B: Iron deficiency anemia. In: Nelson Textbook of pediatrics $18^{\text {th }}$ ed, edsKliegman RM, Behrman RE, Jenson HB and Stanton BF. Saunders: 2014-2017, 2007.

$>$ Karine, Tolentino, Jennifer F, et al.: An Update on Anemia in Less Developed Countries. Am J Trop Med Hyg77(1): 44-51, 2007.

\section{>Kaushansky K, Lichtman M , Kipps T, Seligsohn}

U, Prchal J. Hematology of the fetus and newborn. In: Kaushansky k, Lichtman M, Kipps T, eds., Williams Hematology, $8^{\text {th }}$ ed. The McGraw-Hill Companies, 2010; pp: 115-138

>Kirsten E. Crowley, MD June, 2005.

>Melind Ratini, Do, Ms January 10, 2017 member of web MD Medical review team web MD.Retrieved 27. 


\section{$>$ Rumi Debbarma, Birakta Debbarma, Prof. M.}

Antia Dev.Post- Graduate Trainee, Deptt.Of

Physiology, Regional institute of Medical Sciences, Imphal, Manipur, Senior resident, Deptt. Of Medicine, AttMs, New Delhi, India.HOD, Deptt. Of physiology, Regional Institute of Medical Sciences (RIMS), Imphal, India (July, 2015).

Singla P.N, chands.Effect of maternal Anemia on the placenta and the new born infant.Acta Paediatrica. June 2008, 67 (5): 645- 648

DSwetha, K., Tarakeswararao, P., \& Saisunilkishore, M. (2017). Relationship between maternal iron and cord blood iron status: A prospective study.

$>$ Van Meter K: A systematic review of the application of hyperbaric oxygen in the treatment of severe anemia. Undersea Hyper Med 32 (1): 61-83, 2008. 


\section{Table (1) : Sex characteristics of study neonates $(\mathrm{N}=200)$}

\begin{tabular}{|c|c|c|}
\hline Variable & $\mathrm{N}$ & $\%$ \\
\hline Male & 83 & 41.5 \\
\hline Female & 117 & 58.5 \\
\hline
\end{tabular}

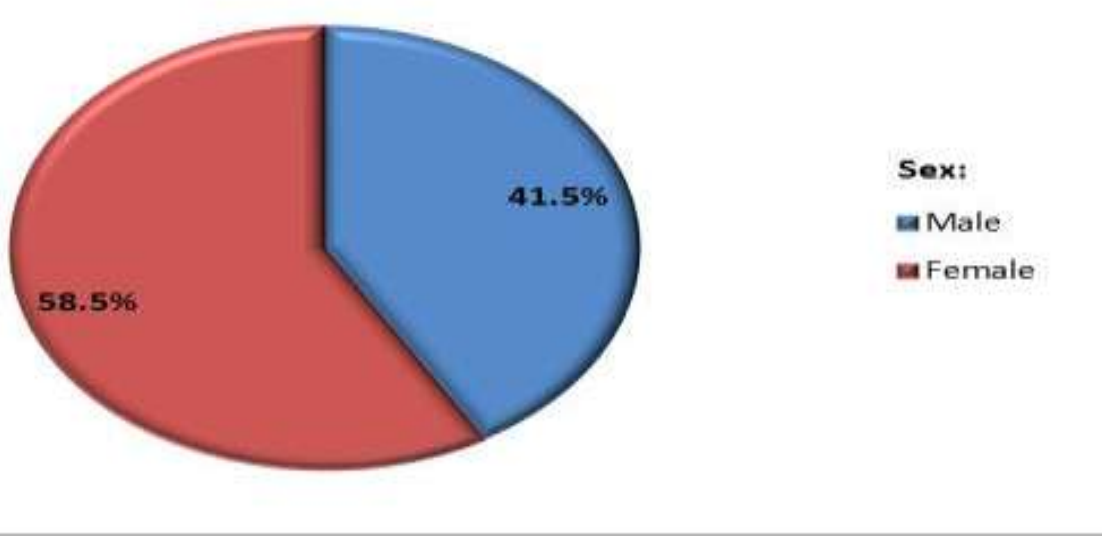

Table (1) and figure (1) show that in our study group neonates, female were $117 / 200(58.5 \%)$ while male constituted $41.5 \%$ of them.

Table (2): Hb and ferritin in study neonates $(\mathrm{N}=200)$

\begin{tabular}{|r|r|r|}
\hline Variable & Mean \pm SD & \multicolumn{1}{|c|}{ Median (Range) } \\
\hline$\underline{\text { Hemoglobin }}$ & $12.61 \pm 2.44$ & $12.2(8.3-17.9)$ \\
\hline$\underline{\text { Ferritin }}$ & $104.96 \pm 98.17$ & $65.11(7.49-507.68)$ \\
\hline
\end{tabular}

Table (2) reveals that mean \pm SD of HB and Ferritin were: $12.61 \pm 2.44$ and $104.96 \pm 98.17$, respectively. 
Table (3): Ferritin deficiency in study neonates $(\mathrm{N}=200)$

\begin{tabular}{|r|c|c|}
\hline Variable & $\mathbf{N}$ & \% \\
\hline \hline $\begin{array}{r}\text { New born withFerritin } \\
\text { deficiency }\end{array}$ & 24 & 12.0 \\
\hline Normal & 176 & 88.0 \\
\hline
\end{tabular}

Ferritin deficiency is diagnosed by serum Ferritin level below $25 \mathrm{ng} / \mathrm{ml}$

(MelindRatini, Do, Ms 2017).

About one eighth of studied neonates 24/200 (12.0\%) had Ferritin deficiency.

Figure (3): Ferritin deficiency in study neonates

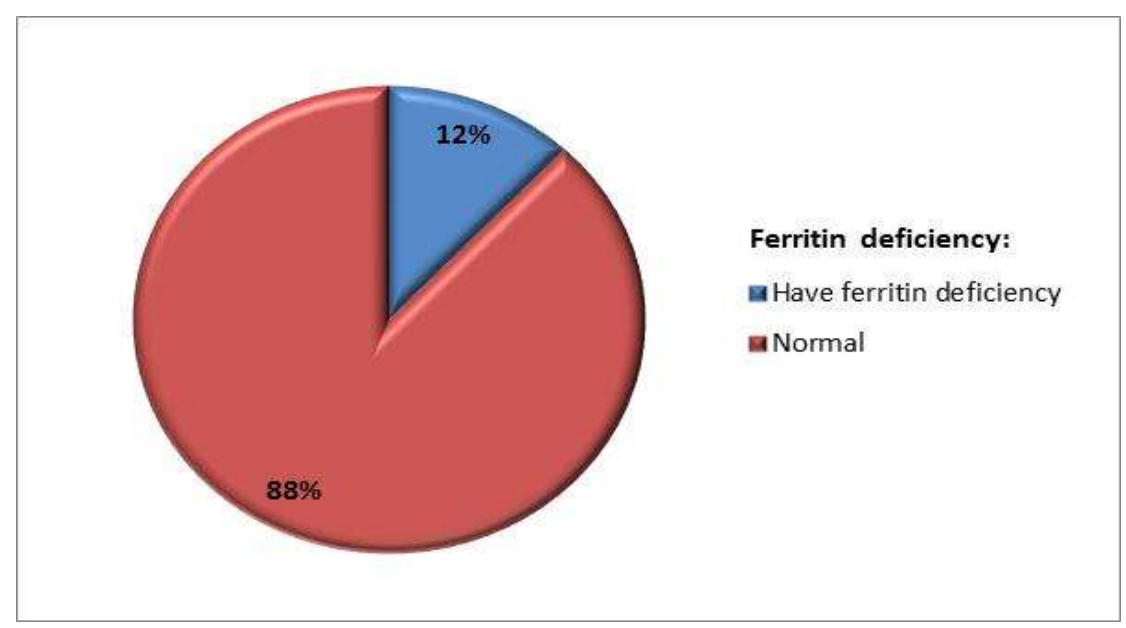

